\title{
THE MODELS OF CHECKLIST METHOD IN EVALUATING ELT TEXTBOOKS
}

\author{
Harni Jusuf \\ harni.jusuf@yahoo.co.id \\ English Education Department of Tarbiyah and Teacher Training Faculty \\ The State Institute of Islamic Studies (IAIN) Sultan Amai Gorontalo, Indonesia
}

\begin{abstract}
There are four interrelated aspects in teaching learning process that is teacher, students, materials, and evaluation and assessment. The things that should be paid attention related to materials are materials selection, materials development and design, and materials evaluation or textbook evaluation. Regarding to textbook evaluation, this article aims to describe one of the three methods of textbook evaluation, checklist method. It discusses what checklist method is and some suggested checklist method that can be used in evaluating textbook. There are fifth different checklist models displayed in this article. They include Tucker (1975), Daoud and Celce-Murcia (1979), William (1983), Sheldon (1988), and Cunningsworth (1995). The fifth models are quoted from journals and books.

Ada empat aspek yang saling terkait dalam proses belajar mengajar yaitu guru, siswa, materi, dan evaluasi dan penilaian. Hal-hal yang harus diperhatikan terkait materi adalah pemilihan bahan, pengembangan dan desain material, dan evaluasi bahan atau evaluasi buku teks. Mengenai evaluasi buku teks, artikel ini bertujuan untuk menggambarkan salah satu dari tiga metode evaluasi buku teks, metode daftar periksa. Ini membahas metode checklist apa dan beberapa metode checklist yang disarankan yang dapat digunakan dalam mengevaluasi buku teks. Ada lima model checklist berbeda yang ditampilkan dalam artikel ini. Mereka termasuk Tucker (1975), Daoud dan Celce-Murcia (1979), William (1983), Sheldon (1988), dan Cunningsworth (1995). Model kelima dikutip dari jurnal dan buku.
\end{abstract}

Key words: teaching learning process, textbook evaluation, checklist method 


\section{A. Introduction}

In teaching learning process, textbook has an important role because it leads teachers in conveying materials to be taught over a period of time. Also, for students, textbook make them easier to understand what are being taught. With textbook, students can learn the lesson/topic at home. Regarding to the importance of textbook, Cunningsworth as cited in Demir states that the roles of ELT course book are serving to present the written and spoken materials, promoting interaction, serving as reference of vocabulary and grammar, acting as a source for classroom activities and offering selfaccess work or self-directed learning.

Talking about textbook, there is one interesting thing to be discussed, that is textbook evaluation. According to Ahour, Towhidiyan, and Saeidi, "textbook evaluation is a requisite to qualifying the content of the textbook and homogenizing it with the teaching/learning requirements in EFL/ESL settings". Textbook itself should be evaluated because of some reasons. Hutchinson and Waters as cited in Ahour, Towhidiyan, and Saeidi say that the aim of textbook evaluation is "to determine the suitability of the materials to our particular purpose". Cunningsworth cited in Alshehri argues that the reasons for evaluating textbook are to adopt new course books, to find out the particular strengths and weakness, and to aid in the development of teachers and provide insights into a textbook's various components. Contrary to the both former experts, Tomlinson says that why textbook should be evaluated because it provides teachers with insights into the application of language theories.

\section{B. Literature Review}

In the light of textbook evaluation, many researches over the worlds have been carried out in different content and perspectives. A study conducted by Sarem, Hamidi, and Mahmoudie (2013) evaluate the specialized book of English for International Tourism based on the checklist developed by Daoud and Celce-Murcia. The obtained results showed that the current book can be used as an acceptable textbook to teach to students who are interested in studying tourism.

Two studies in the same year (2014) conducted by Ahour, Towhidiyan, and Saeidi, and Rashidi and Kehtarfard. Ahour, Towhidiyan, and Saeidi investigate the appropriateness of "English Textbook 2" for Iranian EFL second grade high school 
Journal al-Lisan

ISSN 2442-8965 \& E ISSN 2442-8973

Volume 3 Nomor 2 - Agustus 2018

http://journal.iaingorontalo.ac.id/index.php/al

students from the teachers' perspectives. The participants of the study consisted of 25 English teachers (8 females and 17 males) randomly selected from different high schools in Boukan, Iran. The evaluation of the textbook was conducted quantitatively through an adapted checklist developed by Litz. The results of the study revealed that teachers' perceptions about these criteria were not favorable in general. Rashidi and Kehtarfard (2014) reports on the findings of a study conducted to evaluate an English textbook (the third-grade high school English book), which is being used in all state high schools in Iran by using a needs analysis framework. The results of the textbook evaluation revealed that although all language skills and components were almost important for the majority of the students, the textbook could not fully support all of them together.

Another study, Alshehri (2016), evaluate Cutting Edge, a textbook which is currently being taught at Najran University's Preparatory Year Programme. Twelve EFL instructors were asked to share their perspectives about the target textbook, and a forty-item questionnaire, which was developed by Litz was used for the purposes of the evaluation. The study's findings revealed that the instructors were largely satisfied with a majority of the textbook's features. They were most satisfied with the textbook's layout and design (mean score=3.74), followed by its subject and content (3.65), its skills component (3.63), its activities (3.55) and its language type (3.51). By contrast, the respondents' opinions of the textbook's practical considerations were unclear. Meanwhile, Hussin, Nimehchisalem, Kalajahi, and Yunus (2016) evaluate the presentation of new vocabulary items in the Form Three English language textbook used in Secondary Schools in Malaysia. A group of purposively selected teachers $(\mathrm{n}=$ 5) used a checklist to evaluate the presentation of vocabulary items in the textbook. The findings showed that the textbook is weak in vocabulary presentation. It was found that no specific method was followed to teach the new vocabulary. There was no index of the new vocabulary at the end of the textbook. The results have implications for the learners, English language teachers as well as textbook developers.

Bouzid, Erguig, and Yeou (2016) conducted a study which investigate ways in which textbook evaluation can help in implementing a positive change in EFL teachers' professional careers. It draws the attention of Moroccan high school English language 
Journal al-Lisan

ISSN 2442-8965 \& E ISSN 2442-8973

Volume 3 Nomor 2 - Agustus 2018

http://journal.iaingorontalo.ac.id/index.php/al

practitioners to the viability of using textbook evaluation as a reflective practice to enhance teachers' professional development. A survey was designed to explore the attitudes of Moroccan high school English language teachers towards the suggested model of textbook evaluation and its ability to promote teachers' professional development. The findings demonstrated that the teachers were in favor of the suggested textbook evaluation model.

A study entitled "A Comparison of Teaching Materials (School Textbooks Vs Authentic Materials) from the Perspective of English Teachers and Educational Supervisors in Saudi Arabia" was conducted by Allehyani, Burnapp, and Wilson (2017). They explore English teachers' and educational supervisors' attitudes to using school textbooks and authentic materials in Saudi boys' schools. Specifically, it aims to determine the preferred teaching materials (either textbooks or authentic materials which are not usually recommended in the current textbooks (or which are additional to the contents of the current textbooks) from the participants' points of view. A mixed research approach - quantitative and qualitative - was used to investigate the favored teaching materials, while the contrastive research approach allowed both types to be evaluated. The results showed that the participants had positive attitudes to using authentic materials and that most teachers preferred them to school textbooks.

One of the seventh previous researches (Demir, 2014) is a development research in which he designed the eclectic checklist for ELT course book evaluation. Meanwhile, the others are based research. The difference of this study with the others that is this study is a library research which focus on suggested checklist method that can be used in evaluating textbook. In this theoretical studies, this article purposes to describe 2 things related to textbook evaluation, namely: (1) what checklist method is; and (2) various models of checklist method.

\section{Research Method}

The method used in writing this article is descriptive qualitative method. The using of this method aims to describe two things, namely checklist method to evaluate book text and some models of checklist method. 
Journal al-Lisan

ISSN 2442-8965 \& E ISSN 2442-8973

Volume 3 Nomor 2 - Agustus 2018

http://journal.iaingorontalo.ac.id/index.php/al

\section{Findings and Discussion}

\section{Checklist as the Method of Textbook Evaluation}

One of the three methods that can be used in evaluating textbook is checklist method. The checklist method is an instrument that helps practitioners evaluate course books in an effective and practical way. Meanwhile, Sarem, Hamidi, and Mahmoudie state that checklist is an instrument that provides the evaluator with a list of features of successful learning-teaching materials. According to these criteria, evaluators like teachers, researchers, as well as students can rate the quality of material. Based on these definitions, I conclude that checklist is an instrument to assess the worth of materials along with some determined aspects.

According to McGrath, there are four advantages of checklist method as follow.

1) It is systematic, ensuring that all elements that are deemed to be important are considered.

2) It is effective, permitting a good deal of information to be recorded in a relatively short space of time.

3) The information is recorded in a convenient format, allowing for easy comparison between competing sets of material.

4) It is explicit, and, provided the categories are well understood by all involved in the evaluation.

\section{Various Models of Checklist Method}

\section{1) Tucker (1975)}

Tucker divides his checklist into two main criteria. External criteria and internal criteria, which is consists of 3 categories. The third categories of internal criteria are pronunciation criteria, grammar criteria, and content criteria. The special features of this checklist are:

a. Tucker uses terms value scale (importance in context) and merit scale (quality) to assess the textbook.

b. Value scale range from 0-5 and merit scale range from 0-4.

c. The checklist has VMP (value merit product), the multiplication result of VS and MS. The scores from multiplication not only an arithmetical total but also a graph in which the actual and ideal profiles can be displayed 
Tucker's checklist model of textbook evaluation method is as follow.

TABLE 1. Tucker's ELT Textbook Evaluation Checklist

\begin{tabular}{|c|c|c|c|c|}
\hline NO. & CRITERIA & VS & MS & MVP \\
\hline $\begin{array}{l}1 . \\
2 . \\
3 .\end{array}$ & $\begin{array}{l}\text { I. INTERNAL CRITERIA } \\
\text { A. Pronunciation Criteria } \\
\text { Completeness of presentation } \\
\text { Appropriateness of presentation } \\
\text { Adequacy of practice }\end{array}$ & & & \\
\hline $\begin{array}{l}4 . \\
5 . \\
6 . \\
7 .\end{array}$ & $\begin{array}{l}\text { B. Grammar Criteria } \\
\text { Adequacy of pattern inventory } \\
\text { Appropriate sequencing } \\
\text { Adequacy of drill model and pattern displayed } \\
\text { Adequacy of practice }\end{array}$ & & & \\
\hline $\begin{array}{r}8 . \\
9 . \\
10 .\end{array}$ & $\begin{array}{l}\text { C. Content Criteria } \\
\text { Functional load } \\
\text { Rate and manner of entry and re-entry } \\
\text { Appropriate of contents and situations }\end{array}$ & & & \\
\hline
\end{tabular}

11. Authenticity of language

12. Availability of supplementary materials

13. Adequate guidance for non-native teachers

14. Competence of the author

15. Appropriate level for integration

16. Durability

17. Quality of editing and publishing

18. Price and value

VS: value scale $\quad$ MS: merit scale $\quad$ VMP: value merit product

\section{2) Daoud and Celce-Murcia (1979)}

Marianne Celce-Murcia is a Professor Emerita of Applied Linguistics at the University of California, Los Angeles (UCLA). Her interests include English grammar and pronunciation. She has been (co)editor on all four editions of TES/FL ( $4^{\text {th }}$ edition, forthcoming, National Geographic-Heinle) as well as co-editing a fivevolume textbook series with M. Sokolik. Celce-Murcia has served as a member-atlarge on the Boards of both Teachers of English to Speakers of Other Language (international TESOL) and the American Association for Applied Linguistics (AAAL).

Daoud and Celce-Murcia checklist for textbook evaluation consists of five aspects. The first is subject matter, the second is vocabulary and structures, the third 
is exercises, the fourth is illustrations, and the fifth is physical make-up. The total items of the five aspects are 25 .

TABLE 2. Daoud and Celce-Murcia ELT Textbook Evaluation Checklist

\begin{tabular}{lllllll}
\hline No & Item & \multicolumn{4}{c}{ Response } \\
\cline { 2 - 5 } & & SD & D & U & A & SA \\
\hline
\end{tabular}

\section{A. Subject matter}

1. Does the subject matter cover a variety of topics appropriate to the interests of the learners for whom the text book is intended (urban or rural environment; child or adult learners; male and/or female students)?

2. Is the ordering of materials done by topics or themes that are arranged in a logical fashion?

3. Is the content graded according to the needs of the students or the requirements of the existing syllabus (if there is one)?

4. Is the material accurate and up-to-date?

\section{B. Vocabulary and structures}

5. Does the vocabulary load (i.e., the number of new words introduced every lesson) seem to be reasonable for the students of that level?

6. Are the vocabulary items controlled to ensure systematic gradation from simple to complex items?

7. Is the new vocabulary repeated in subsequent lessons for reinforcement?

8. Does the sentence length seem reasonable for the students of that level?

9. Is the number of grammatical points as well as their sequence appropriate?

10. Does the structure gradually increase in complexity to suit the growing reading ability of the students?

11. Does the writer use current everyday language, and sentence structures that follow normal word order?

12. Do the sentences and paragraphs follow one another in a logical sequence?

13. Are linguistic items introduced in meaningful situations to facilitate understanding and ensure assimilation and consolidation?

\section{Exercises}

14. Do the exercises develop comprehension and test knowledge of main ideas, details, and sequence of ideas?

15. Do the exercises involve vocabulary and structures 


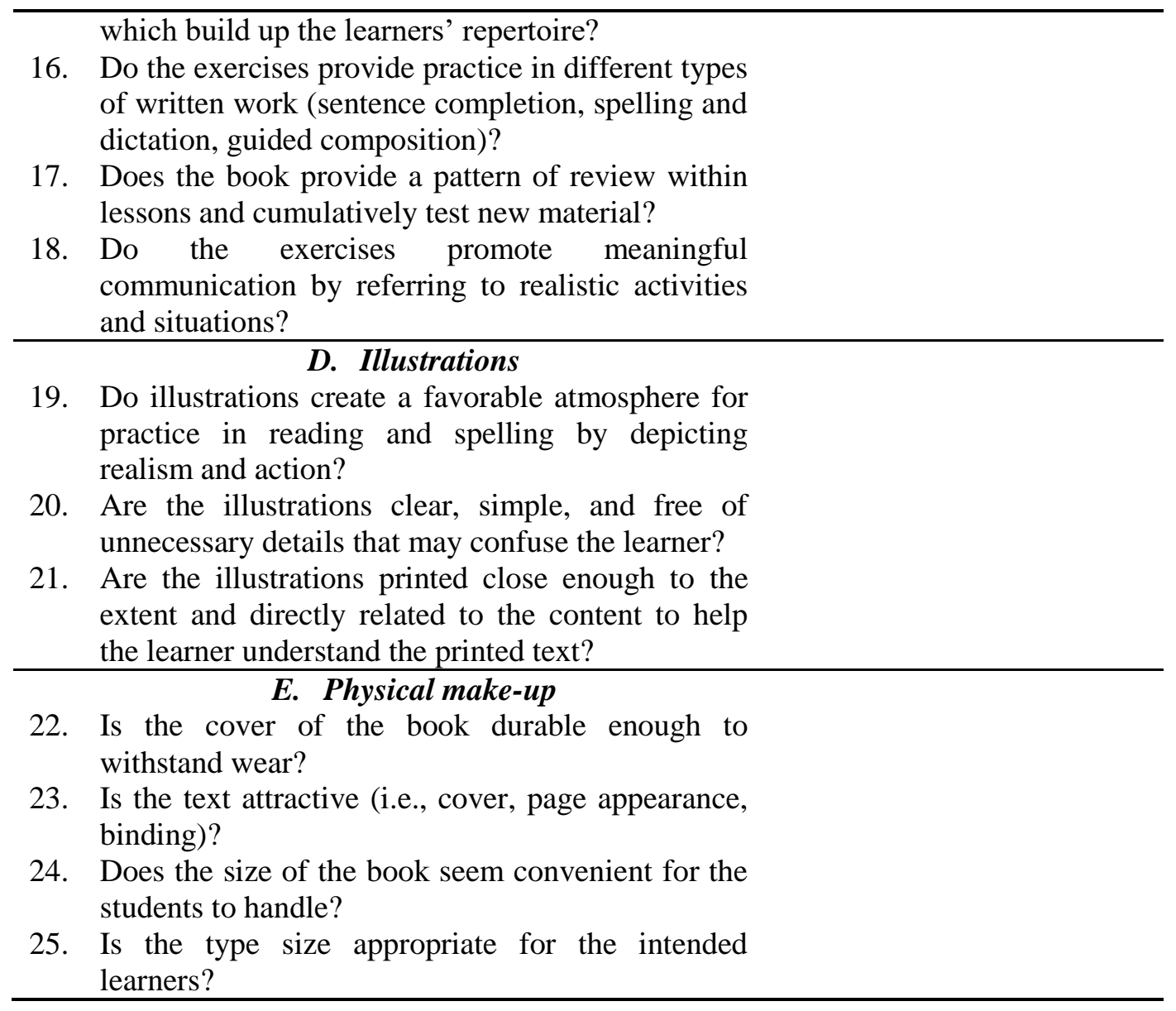

1: Strongly disagree 2: Disagree U: Undecided A: Agree SA: Strongly Agree

\section{3) Williams (1983)}

David Williams is a Senior Lecturer and Head of the Language Arts Section in the Department of Education, Ahmadu Bello University, Nigeria. He holds a doctorate in Education from the University of Malaya. His current research interests include reading comprehension, the teaching of literature, and attitudes towards varieties of spoken and written Nigerian English.

Williams splits his ELT textbook checklist into 7 criteria. The seventh criteria are general, speech, grammar, vocabulary, reading, writing, and technical. The special features of his textbook checklist are:

a. Column for weighting on the left of the checklist. Weighting can be indicated by numbers or letters (e.g. 4: very useful, 3: quite useful, 2: fairly useful, and 1: not so useful). This left column can be used for weighting items according to their 
usefulness in a particular second-language context, or at a particular educational level.

b. The 5-point numerical rating scale on the right of the checklist. It can be used for adapting evaluative items to suit the particular demands of the teaching situation. The numbers given in the right-hand column indicate the extent to which a given textbook satisfies each criterion on the checklist.

c. Sets of criteria can be evolved for comparative evaluations by multiplying the weighting of each item by the rating on each item.

In the following is the table of Williams' ELT textbook evaluation checklist.

TABLE 3. Williams' ELT Textbook Evaluation Checklist

\section{Title of textbook:}

This textbook: $\quad$ Rating

Weight

A. GENERAL

1. Takes into account currently accepted methods of ESL/EFL teaching.

2. Gives guidance in the presentation of language items.

3. Caters for individual differences in home language background.

4. Relates content to the learners' culture and environment.

\section{B. SPEECH}

5. Is based on a contrastive analysis of English and LI sound systems.

6. Suggests ways of demonstrating and practising speech items.

7. Includes speech situations relevant to the pupils* background.

8. Allows for variation in the accents of non-native speakers of English

9. Stresses communicative competence in teaching structural items.

10. Provides adequate models featuring the structures to be taught.

11. Shows clearly the kinds of responses required in drills (e.g. Substitution).

12. Selects structures with regard to differences between LI and L 2 cultures.

\section{VOCABULARY}

13. Selects vocabulary on the basis of frequency, functional load, etc.

14. Distinguishes between receptive and productive skills in vocabulary teaching.

15. Presents vocabulary in appropriate contexts and situations.

16. Focuses on problems of usage related to social background.

\section{E. READING}


17. Offers exercises for understanding of plain sense and implied meaning.

18. Relates reading passages to the learners' background.

19. Selects passages within the vocabulary range of the pupils.

20. Selects passages reflecting a variety of styles of contemporary English.

\section{F. WRITING}

21. Relates written work to structures and vocabulary practiced orally.

22. Gives practice in controlled and guided composition in the early stages.

23. Relates written work to the pupils' age, interests, and environment.

24. Demonstrates techniques for handling aspects of composition teaching.

\section{G. TECHNICAL}

25. Is up-to-date in the technical aspects of textbook production and design.

26. Shows quality in editing and publishing (cover, typeface, illustrations, etc.).

27. Is datable, and not too expensive.

28. Has authenticity in language and style of writing.

0: not at all 1 : just barely 2 : to some extent $3:$ to a large extent $4:$ to the greatest extent

\section{4) Sheldon (1988)}

Leslie Sheldon is Director of ELT, Pitman Education and Training Ltd. He has taught at schools, universities, and teacher-training establishments in Canada, Iran, Algeria, Italy, Sweden and the UK, as well as having been an ESP consultant. In 1989 Dr Sheldon directed a British Council specialist seminar held in the UK, entitled 'ELT Textbooks and Materials: Evaluation, Exploitation, Adaptation and Design'.

Sheldon designed his textbook checklist into 17 factors. The total items of the seventeenth factors are 53. The special features of his checklist are: (1) factual details (at the top of the checklist), (2) column comment for adding our comment about each factor, and (3) column for rating, which can be scored with pluses and minuses, or stars, etc.), but, in this article I use poor, fair, good, and excellent for the rating scale. Sheldon textbook evaluation checklist can be seen as follow. 


\section{FACTUAL DETAILS}

Title:

Author(s):

Publisher:. Price:

ISBN: No. of Pages:

Components: SB/TB/WB/Tests/Cassettes/Video/CALL/Other

Level: Physical size:

Length: Units. Lessons/sections Hours

Target skills:

Target learners:

Target teachers:

ASSESSMENT (* Poor ** Fair *** Good **** Excellent)

\begin{tabular}{lll}
\hline No. & \multicolumn{3}{c}{ Rating } \\
\cline { 2 - 3 } & & Comments \\
& & F G G E \\
\hline
\end{tabular}

\section{A. Rationale}

1. Why was the book written in first place, and what gaps is it intended to fill?

2. Are you given information about the Needs Analysis or classroom piloting that was undertaken?

3. Are the objectives spelt out?

\section{B. Availability}

4. Is it easy to obtain sample copies and support material for inspection?

5. Can you contact the publisher's representatives in case you want further information about the content, approach, or pedagogical detail of the book?

\section{User definition}

6. Is there a clear specification of the target age range, culture, assumed background, probable learning preferences, and educational expectations?

7. Are entry/exit language levels precisely defined, e.g. by reference to international 'standards' such as the ELTS, ACTFL or Council of Europe scales, or by reference to local or country-specific examination requirements?

8. In the case of an ESP textbook, what degree of specialist knowledge is assumed (of both learners and teacher)?

\section{Layout/graphics}

9. Is there an optimum density and mix of text and graphical material on each page, or is the impression one of clutter?

10. Are the artwork and typefaces functional? Colorful? Appealing?

\section{E. Accessibility}

11. Is the material clearly organized?

12. Can the student find his or her location in the material at any point, i.e. is it possible to have a clear view of the 'progress' made, and how much still needs to be 
covered?

13. Are there indexes, vocabulary lists, section headings, and other methods of signposting the content that allow the student to use the material easily, especially for revision or self-study purposes?

14. Is the learner (as opposed to the teacher) given clear advice about how the book and its contents could be most effectively exploited?

\section{F. Linkage}

15. Do the units and exercises connect in terms of theme, situation, topic, pattern of skill development, or grammatical/lexical 'progression'?

16. Is the nature of such connection made obvious, for example by placing input texts and supporting exercises in close proximity?

17. Does the textbook cohere both internally and externally (e.g. with other books in a series)?

\section{G. Selection/Grading}

18. Does the introduction, practice, and recycling of new linguistic items seem to be shallow/steep enough for your students?

19. Is there a discernible system at work in the selection and grading of these items (e.g. on the basis of frequency counts, or on the basis of useful comparisons between the learner's mother tongue and English)?

20. Is the linguistic inventory presented appropriate for your purposes, bearing in mind the L1 background(s) of your learners?

\section{H. Physical characteristics}

21. Is there space to write in the book?

22. Is the book robust? Too large? Too heavy?

23. Is the spine labeled?

24. Is it a book that could be used more than once, especially if it is marked by previous students?

\section{Appropriacy}

25. Is the material substantial enough or interesting enough to hold the attention of learners?

26. Is it pitched at the right level of maturity and language, and (particularly in the case of ESP situations), at the right conceptual level?

27. Is it topical?

\section{J. Authenticity}

28. Is the content obviously realistic, being taken from L1 material not initially intended for ELT purposes?

29. Do the tasks exploit language in a communicative or 'real-world' way?

30. If not, are the texts unacceptably simplified or artificial (for instance, in the use of whole-sentence dialogues)? 


\section{K. Sufficiency}

31. Is the book complete enough to stand on its own, or must the teacher produce a lot of ancillary bridging material to make it workable?

32. Can you teach the course using only the student's book, or must all the attendant aids (e.g. cassettes) be deployed?

\section{Cultural bias}

33. Are different and appropriate religious and social environments catered for, both in terms of the topics/situations presented and of those left out?

34. Are students' expectations in regard to content, methodology, and format successfully accommodated?

35. If not, would the book be able to wean students away from their preconceived notions?

36. Is the author's sense of humor or philosophy obvious or appropriate?

37. Does the course book enshrine stereotyped, inaccurate, condescending or offensive images of gender, race, social class, or nationality?

38. Are accurate or 'sanitized' views of the USA or Britain presented; are uncomfortable social realities (e.g. unemployment, poverty, family breakdowns, and racism) left out?

\section{Educational validity}

39. Does the textbook take account of, and seem to be in tune with, broader educational concerns (e.g. the nature and role of learning skills, concept development in younger learners, the function of 'knowledge of the world', the exploitation of sensitive issues, and the value of metaphor as a powerful cognitive learning device)?

\section{N. Stimulus/practice/revision}

40. Is the course material interactive, and are there sufficient opportunities for the learner to use his or her English so that effective consolidation takes place?

41. Is the material likely to be retained/ remembered by learners?

42. Is allowance made for revision, testing, and on-going evaluation/marking of exercises and activities, especially in large-group situations; are ready-made achievement tests provided for the course book, or is test development left for the hard-pressed teacher? Are 'selfchecks' provided?

\section{o. Flexibility}

43. Can the book accommodate the practical constraints with which you must deal, or are assumptions made about such things as the availability of audio-visual equipment, pictorial material, class size, and classroom geography; does the material make too many demands 
on teachers' preparation time and students' homework time?

44. Can the material be exploited or modified as required by local circum- stances, or is it too rigid in format, structure, and approach?

45. Is there a full range of supplementary aids available?

\section{P. Guidance}

46. Are the teacher's notes useful and explicit? English?

47. Has there been an inordinate delay between the publication of the student's and teacher's books which has meant that teachers have had to fend for themselves in exploiting the material?

48. Is there advice about how to supplement the course book, or to present the lessons in different ways?

49. Is there enough/too much 'hand-holding'?

50. Are tape scripts, answer keys, 'technical notes' (in the case of ESP textbooks), vocabulary lists, structural/functional inventories, and lesson summaries provided in the Teacher's Book?

51. Is allowance made for the perspectives, expectations, and preferences of non-native teachers of English?

\section{$Q$. Overall value for money}

52. Quite simply, is the course book cost-effective, easy to use, and successful money in your teaching situation, in terms of time, labor, and money?

53. To what extent has it realized its stated objectives?
1: poor
2: fair
3: good
4: excellent

\section{5) Cunningsworth (1995)}

Cunningsworth checklist for textbook evaluation consists of eight aspects.

They are aim and approaches, design and organization, language content, skills, topic, methodology, teachers' books, and practical consideration. The total items of the eighth aspects are 44. The special feature of his checklist is using Yes/No questions.

TABLE 5. Cunningsworth's ELT Textbook Evaluation Checklist

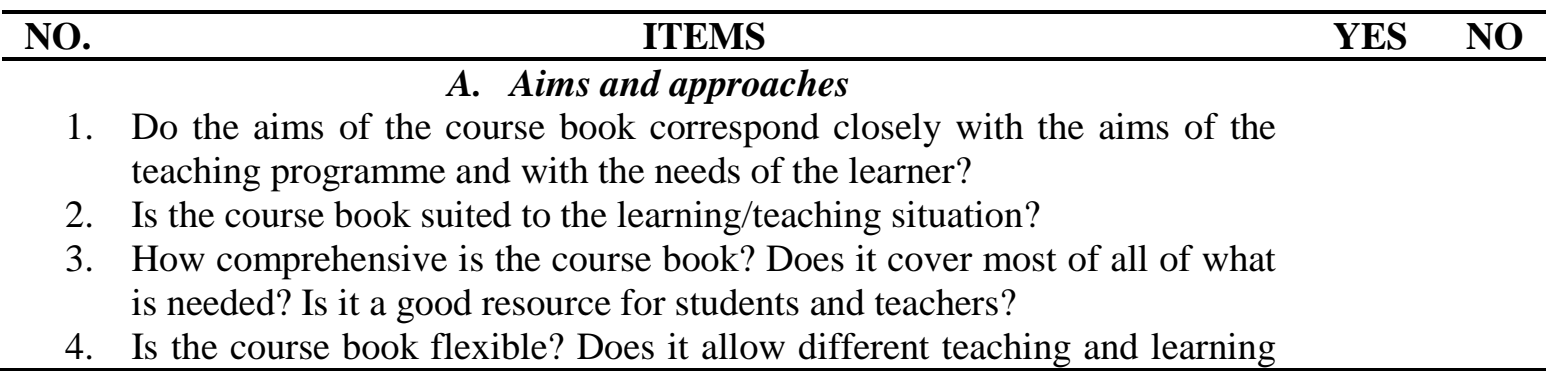




\section{styles?}

\section{B. Design and organization}

5. What components make up the total course package (e.g., students' books, teacher's books, workbooks, cassettes)?

6. How is the content organized (e.g., according to structures, functions, topics, skills, etc.)?

7. How is the content sequenced (e.g., on the basis complexity, "learnability," usefulness, etc.)?

8. Is the grading and progression suitable for the learners? Does it allow them to complete the work needed to meet any external syllabus requirements?

9. Are the reference sections for grammar, etc.? Is some of the material suitable for individual study?

10. Is it easy to find your way around the course book? Is the layout clear?

\section{Language content}

11. Does the course book cover the main grammar items appropriate to each level, taking learners' needs into account?

12. Is material for vocabulary teaching adequate in terms of quantity and range of vocabulary, emphasis placed on vocabulary development, strategies for individual learning?

13. Does the course book include material for pronunciation work? If so, what is covered: individual sounds, word stress, sentence stress, intonation?

14. Does the course book deal with the structuring and conventions of language use above sentence level, for example, how to take part in conversations, how to structure a piece of extended writing, how to identify the main points in a reading passage? (More relevant at intermediate and advanced levels).

15. Are style and appropriacy dealt with? If so, is language style matched so social situation?

16. Are all four skills adequately covered, bearing in mind your course aims and syllabus requirements?

17. Is there material for integrated skill work?

18. Are reading passages and associated activities suitable for your students' level, interests, etc.? Is there sufficient reading material?

19. Is listening material well recorded, as authentic as possible, accompanied by background information, questions, and activities which help comprehension?

20. Is material for spoken English (dialogues, role plays, etc.) well designed to equip learners for real-life interactions?

21. Are writing activities suitable in terms of amount of guidance/control, degree of accuracy, organization of longer pieces of writing (e.g., paragraphing) and use of appropriate styles?

\section{E. Topic}

22. Is there sufficient material of genuine interest to learners?

23. Is there enough variety and range of topic?

24. Will the topics help expand students' awareness and enrich their experience?

25. Are the topic sophisticated enough in content, yet within the learners' 


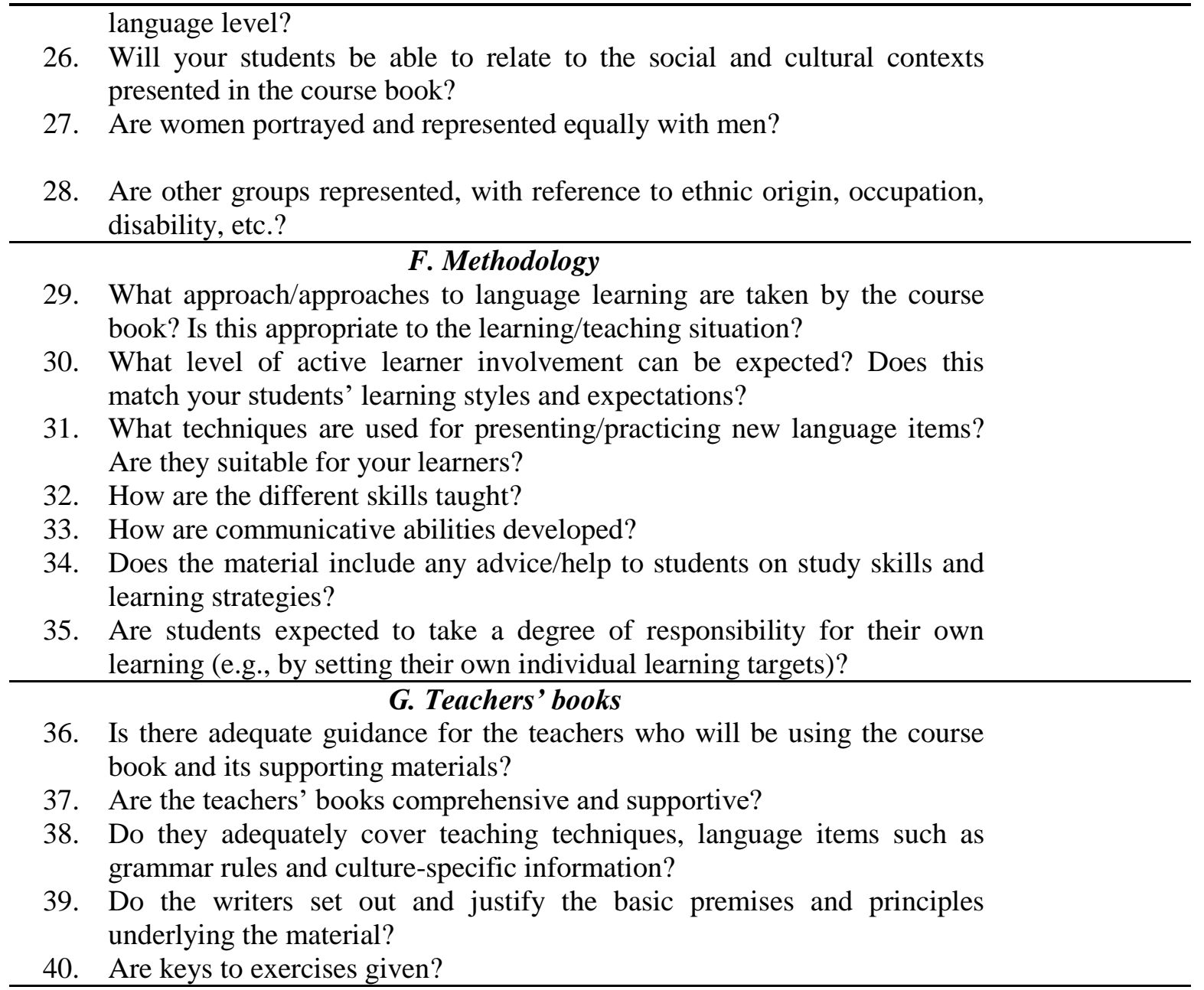

\section{E. Practical consideration}

41. What does the whole package cost? Does this represent good value for money?

42. Are the books strong and long-lasting? Are they attractive in appearance?

43. Are they easy to obtain? Can further supplies be obtained at short notice?

44. Do any parts of the package require particular equipment, such as a language laboratory, listening centre, or video player? If so, do you have the equipment available for use and is it reliable?

\section{E. Conclusions}

Based on the discussions of checklist model above, it can be concluded that everyone can use the desired checklist model of textbook evaluation that suits his/her needs. We also can make our questionnaire by modifying the existing models or design it by ourselves through research. Evaluation of textbooks is necessary to do as worthy input or not a textbook is used in the learning process. However, the determination of 
Journal al-Lisan

ISSN 2442-8965 \& E ISSN 2442-8973

Volume 3 Nomor 2 - Agustus 2018

http://journal.iaingorontalo.ac.id/index.php/al

whether or not the book deserves depends not only on the judgment of someone or several person, but on some consideration.

The eighth checklist models have similarities and differences. The designers of checklist models create their questionnaire based on some principles. The other adapt and/or revise the formers design by adding, deleting, or reword the items of questionnaire. Even though the checklist model has advantages, it also has weakness. The checklist cannot give the descriptive reasons why respondents give a such score on the item/s in the questionnaire. 


\section{REFERENCES}

Ahour, T., Towhidiyan, B., \& Saedi, M. (2014). The evaluation of "English textbook 2" taught in Iranian high schools from teachers' perspectives. English Language Teaching, 7(3), 150-158. doi:10.5539/elt.v7n3p150

Ait Bouzid, H., Erguig, R., \& Yeou, M. (2016). Towards a reflective textbook evaluation model. EFL Journal, 1(3), 219-233. Doi:http://dx.doi.org/10.21462/eflj.v1i3.21

Allehyani, B., Burnapp, D., \& Wilson, J. (2017). A comparison of teaching materials (school textbooks vs authentic materials) from the perspective of English teachers and educational supervisors in Saudi Arabia. International Journal of English Language and Linguistic Research, 5(2), 1-14

Alshehri, A. (2016). Textbook evaluation: teachers' perspectives on cutting edge. International Journal of English Language Education, 4(2), 91-106. doi:10.5296/ijele.v4i2.9743

Chegeni, N. et.al. (2016). Looking English textbook evaluation: a closer look at "four corners". Theory and Practice in Language Studies, 6(12), 2325-2330. doi:http://dx.doi.org/10.17507/tpls.0612.13

Demir, Y. (2014). A suggested eclectic checklist for ELT coursebook evaluation. The Reading Matrix, 14(2), 243-252

Hussin, N. I. S. M., Nimehchisalem, V., \& Kalajahi, S. A. R. (2016). Evaluating the presentation of new vocabulary items in Malaysian form three English language textbook. Malaysian Journal of Language and Linguistics, 5(1), 60-78

McGranth, I. (2002). Materials evaluation and design for language teaching. Edinburgh, Scotland: Edinburgh University Press

Rashidi, N., \& Kehtarfard, R. (2014). A need analysis approach to the evaluation of Iranian third-grade high school English textbook. SAGE, 1-9. doi:10.1177/2158244014551709

Richards, J. C. (2001). Curriculum development in language teaching. Cambridge, England: Cambridge University Press

Rubdy, R. (2003). Selection of materials. In Tomlinson, B. (Ed.), Developing materials for language teaching (pp. 37-57). London, England: Continuum

Sarem, S. N., Hamidi, H., \& Mahmoudie, R. (2013). A critical look at textbook evaluation: a case study of evaluating an ESP course-book: English for international tourism. International Research Journal of Applied and Basic Science (IRJABS), 4(2), 372-380

Sheldon, L. E. (1988). Evaluating ELT textbooks and materials. ELT Journal, 42(4), 237-246 
Journal al-Lisan

ISSN 2442-8965 \& E ISSN 2442-8973

Volume 3 Nomor 2 - Agustus 2018

http://journal.iaingorontalo.ac.id/index.php/al

Williams, D. (1983). Developing criteria for textbook evaluation. ELT Journal, 37(3), $251-255$ 